\begin{tabular}{|l|l|l||}
\hline \multicolumn{2}{|c|}{ PublisherInfo } \\
\hline \hline PublisherName & $:$ & BioMed Central \\
\hline \hline PublisherLocation & $:$ & London \\
\hline \hline PublisherImprintName & $:$ & BioMed Central \\
\hline \hline
\end{tabular}

\title{
Dendritic defence
}

\begin{tabular}{|l|l|l||}
\hline \multicolumn{2}{|c|}{ ArticleInfo } \\
\hline \hline ArticleID & $:$ & 4238 \\
\hline \hline ArticleDOI & $:$ & $10.1186 /$ gb-spotlight-20011030-01 \\
\hline \hline ArticleCitationID & $:$ & spotlight-20011030-01 \\
\hline \hline ArticleSequenceNumber & $:$ & 309 \\
\hline \hline ArticleCategory & $:$ & Research news \\
\hline ArticleFirstPage & $:$ & 1 \\
\hline \hline ArticleLastPage & $:$ & 2 \\
\hline \hline & $:$ & RegistrationDate : 2001-10-30 \\
ArticleHistory & $:$ & OnlineDate \\
\hline \hline ArticleCopyright & $:$ & BioMed Central Ltd2001 \\
\hline \hline ArticleGrants & $:$ & \\
\hline \hline ArticleContext & $:$ & 130592211 \\
\hline \hline
\end{tabular}




\section{Jonathan B Weitzman}

Email: jonathanweitzman@hotmail.com

Dendritic cells (DCs) are stalwarts of the immune response, activating both the innate and acquired immune systems. In the October 26 Science, Qian Huang and colleagues at the Whitehead Institute for Biomedical Research describe the use of oligonucleotide microarrays to examine how DCs respond to different pathogens (Science 2001, 294:870-875). They exposed human monocyte-derived DCs to Gram-negative bacteria (Escherichia coli), fungi (Candida albicans) or an RNA virus (influenza virus), and then examined gene expression profiles of around 6,000 genes. They found that 1,330 genes changed upon exposure to at least one of the pathogens. They observed both shared and pathogenspecific changes in gene expression, and classified a common set of 166 regulated genes (the 'core DC response') into functionally related groups. They noted early changes in genes involved in phagocytosis, cytokine production and the cytoskeleton. Later phases were accompanied by changes in signalling genes, transcription factors and stress-response genes. Individual pathogen components, such as bacterial lipopolysaccharide, yeast mannan or double-stranded RNA, mimicked pathogen-induced gene expression programs. Further study of pathogen-specific gene responses should enhance our understanding of how DCs distinguish between different pathogens and provide future targets for immunotherapy.

\section{References}

1. Dendritic cells as sensors of infection

2. Science, [http://www.sciencemag.org]

3. Whitehead Institute for Biomedical Research , [http://wi.mit.edu]

4. Dendritic Cell Gene Expression Database, [http://web.wi.mit.edu/hacohen/dc] 